\title{
Effect of diet and age on jejunal and circulating lymphocyte subsets in children with coeliac disease: persistence of $\mathrm{CD}^{-}{ }^{-}{ }^{-}$intraepithelial $\mathrm{T}$ cells through treatment
}

\author{
M A Verkasalo, A Arató, E Savilahti, V-M Tainio
}

\begin{abstract}
Monoclonal antibodies were used to determine the relative numbers of $T$ lymphocyte subsets in 61 jejunal biopsies and in peripheral blood of 35 children with coeliac disease, and of 13 healthy controls. The $T$ cell numbers in the lamina propria were unaffected by a change from gluten-free to gluten containing diet in the patients. The number of intraepithelial lymphocytes (where the $\mathrm{CD8}^{+}$cells predominated) were significantly raised in patients taking gluten. Ten to $20 \%$ of the patients' intraepithelial $\mathrm{CD3}^{+}$(mature $\mathrm{T}$ ) cells expressed neither CD8 nor CD4 surface antigens. This $\mathrm{CD}^{-} 8^{-} \mathrm{T}$ cell population persisted through gluten elimination and challenge. The circulating lymphocyte subsets showed little variation with the diet although there was a marked increase in the proportion $(14.9 \%)$ of $\mathrm{CD}^{-} 8$ $T$ cells in patients during gluten elimination. In the histologically normal jejunal mucosa from control subjects, the age of the subject showed a positive correlation with villus intraepithelial $\mathrm{CD3}^{+}$and $\mathrm{CD8}^{+}$cells, and crypt intraepithelial CD4 cells. No clear cut effect of age was observed on lamina propria lymphocyte counts of the controls, or on the lymphocyte counts in jejunal mucosa of the coeliac patients. The observed $\mathrm{CD}^{-4}$ 8 $^{-}$lymphocytes may represent activated cells unable to present their surface antigens, or they may be $\gamma \delta$-receptor bearing $T$ cells, which could have a significant role in the pathogenesis of coeliac disease.
\end{abstract}

The human jejunal mucosa harbours a large population of lymphocytes. In lamina propria the lymphocytes are predominantly of the CD4. phenotype, with about $30 \%$ of CD8 cells also present, whereas approximately $85 \%$ of the intraepithelial lymphocytes belong to the $\mathrm{CD}^{+}$ subset. ${ }^{12}$

While it is well known that the relative size of

Children's Hospital, University of Helsinki, Helsinki, Finland M A Verkasalo, A Arató' E Savilahti V-M Tainio Correspondence to: Matti Verkasalo M.D. Matti Verkasalo M. Children's Hospital, University of Helsinki, ki, Finlan Present address: 1st Department of Paediatrics, Semmelweis University, Budapest, Hungary

Accepted for publication 10 July 1989 body lymphoid tissues is great in infancy and diminishes later in childhood, virtually nothing has been reported on the effect of age on intestinal lymphoid cell subsets.

In patients with active coeliac disease the counts of lamina propria lymphocytes and the relative numbers of their subsets are comparable to those in healthy controls. ${ }^{3+}$ The numbers of intraepithelial lymphocytes are increased, ${ }^{5}$ the majority of them being of the CD8 subpopulation. ${ }^{3+67}$ A subgroup of $T$ intraepithelial lymphocytes in adults with active coeliac disease was recently observed, expressing neither CD4. nor CD8 surface markers. The authors suggested that these $T$ cells could be in altered functional state, possibly as committed cytotoxic lymphocytes, and hence not able to fully express their distinct phenotypic markers. ${ }^{8}$

In peripheral blood the proportions of the different lymphocyte subpopulations show little variation with dietary changes in coeliac patients. $^{49}$

We studied the lymphocyte subpopulations in jejunal mucosa and peripheral blood of children with coeliac disease through the diagnostic dietary regimen, and also in healthy control children, in order to clarify the developmental changes in different $T$ cell subsets in intestinal mucosa, and their role in coeliac disease.

\section{Methods}

PATIENTS

During the diagnostic evaluation ${ }^{10}$ of 35 children (19 boys) with coeliac disease, a part of the jejunal biopsy specimen was set aside for this study. The pretreatment biopsy $(n=11)$ was taken at the mean age of $7 \cdot 8$ years (range: $0 \cdot 6$ $15 \cdot 5)$. The second biopsy, taken after an average of $4 \cdot 3$ years on gluten free diet, was available for 20 patients. Of 17 patients who had been taking gluten for a period averaging 4.6 months, we could study the third, or postchallenge biopsy. In 11 children both the second and the third biopsies were available for this study. All children showed jejunal villous atrophy in the first biopsy and marked clinical improvement on gluten free diet. Six patients have not yet been challenged with gluten; they were all four years or older at presentation, two of them have dermatitis herpetiformis and additional two diabetes mellitus.

\section{CONTROLS}

The control group consisted of 13 children (six boys) with mean age of $8 \cdot 2$ years (range: 0.65 to $15 \cdot 2$ ) who were studied for growth retardation. They had neither symptoms nor findings of gastrointestinal disease. The jejunal mucosa was normal in each of them.

TISSUE PROCESSING

Intestinal biopsy specimens were taken from the proximal jejunum with the paediatric Crosby capsule. The specimen was divided immediately into two parts. One half was processed for routine histological examination. The other half 
was embedded in OCT compound (Tissue-Tek 4538, Miles Laboratories Inc, Naperville, Illinois), frozen in freon 22 suspended over liquid nitrogen, and stored at $-70^{\circ} \mathrm{C}$. For further processing $5 \mu$ sections were cut, air dried for one hour, and fixed in acetone at $+4^{\circ} \mathrm{C}$ for 10 minutes. After a 30 minute incubation in chloroform the sections were washed in Tris buffer $(0.01 \mathrm{M}$ Tris $7-9$ in $0.14 \mathrm{M} \mathrm{NaCl}, \mathrm{pH}=$ $7 \cdot 4$, Sigma, St Louis, Missouri).

\section{MONOCLONAL ANTIBODIES}

A panel of commercially available mouse monoclonal antibodies was used to detect lymphocyte surface markers in the specimens. Anti-CD3 antibodies included Tl (Dakopatts, Copenhagen, Denmark), Leu 4 (Beckton Dickinson, Mountain View, California) and OKT3 (Ortho Diagnostic Systems, Raritan, New Jersey); anti CD4 antibodies used were T4 (Coulter Immunology, Hialeah, Florida), Leu 3a 3b (Beckton Dickinson) and OKT 4 (Ortho); CD8 antigens were detected by OKT8 monoclonal antibody (Ortho).

\section{IMMUNOHISTOCHEMICAL METHOD}

The fixed frozen sections were incubated with the monoclonal antibody and washed with Tris buffer. Peroxidase conjugated rabbit antimouse immunoglobulin (Dakopatts, Copenhagen, Denmark) in 1:10 dilution was added. After another wash an incubation with peroxidase conjugated goat antirabbit IgG serum (Tago, Burlingame, California) followed, and a final wash was performed. All of the incubations were carried out at room temperature for 30 minutes; the duration of each wash was 10 minutes. The peroxidase stain was developed with hydrogen peroxide activated AEC (3amino-9-ethylcarbazole, Sigma, St Louis, Missouri) for 20 minutes, and lightly counterstained with hematoxylin. The specimens were mounted in Gurr Aquamount (BDH Chemicals Inc, Poole, England). Similarly processed sections without the first monoclonal antibody were used as controls. They showed only minimal traces of staining indicating that endogenous peroxidase activity had been removed in the process

\section{EVALUATION OF THE MICROSCOPIC SPECIMENS}

The microscopic evaluation was done by one of the authors (AA), who was blinded to the diagnosis. The cell density in the lamina propria was determined with a $0.045 \times 0.045 \mathrm{~mm}$ graticule fitted to the microscope eyepiece counting the number of cells in at least 30 graticules, and expressing the result as cells $/ \mathrm{mm}^{2}$.

In immunoperoxidase stained sections the epithelial cells were only faintly visible, making intraepithelial lymphocyte counting in relation to epithelial cells unreliable. Therefore, we compared this method to counting the intraepithelial lymphocytes along the above-mentioned graticule in $\mathrm{H} \& \mathrm{E}$ stained sections, and found an excellent correlation (Table I). Thus, in further
TABLE I Intraepithelial lymphocyte numbers in $H \mathcal{E} E$ stained sections of jejunal mucosa of children with coeliac disease, and in controls (mean (SEM))

\begin{tabular}{|c|c|c|c|c|}
\hline & \multicolumn{3}{|c|}{ Children with coeliac disease } & \multirow[b]{2}{*}{$\begin{array}{l}\text { Controls } \\
13\end{array}$} \\
\hline & $\begin{array}{l}\text { Before } \\
\text { treatment } \\
n=11\end{array}$ & $\begin{array}{l}\text { Gluten } \\
\text { free diet } \\
n=20\end{array}$ & $\begin{array}{l}\text { Gluten } \\
\text { challenge } \\
n=17\end{array}$ & \\
\hline $\begin{array}{l}\text { IEL/mm } \\
\text { IEL/100 } \\
\text { epith cells }\end{array}$ & $\begin{array}{l}63(10) \dagger \\
33(7) t\end{array}$ & $\begin{array}{l}42(3)^{\star} \\
18(2)^{\star}\end{array}$ & $\begin{array}{l}83(5) \ddagger \\
42(4) \ddagger\end{array}$ & $\begin{array}{l}30(3) \\
12(2)\end{array}$ \\
\hline
\end{tabular}

${ }^{\star}$ Difference from the controls; $\mathrm{p}<0 \cdot 05 ; \uparrow \mathrm{p}<0.01 ; \ddagger \mathrm{p}<0.001$.

work, intraepithelial lymphocytes were counted per epithelial length and expressed as cells/mm of epithelium.

\section{PERIPHERAL BLOOD LYMPHOCYTE}

COUNTING

While taking routine blood tests at the time of the intestinal biopsy a blood sample for lymphocyte subset determination was drawn. The numbers of CD3 (OKT3), CD4 (OKT4) and CD8 (OKT8) positive cells were counted using a previously described indirect immunofluorescent technique."

\section{STATISTICAL ANALYSIS}

For calculation of the statistical significance of the observed differences between the patients and the controls, or patients at different stages of dietary treatment, a computer program was used, applying Student's $t$ test, the Pearson $\chi^{2}$ test, Fisher's exact test or regression analysis, whichever was applicable. ${ }^{12}$

\section{Results}

IMMUNOHISTOCHEMICAL STAINING

The peroxidase labelled cells were readily identifiable on microscopy. The different monoclonal antibodies used for $\mathrm{CD}^{+}$and $\mathrm{CD}^{+}$cells gave similar results for their respective subpopulations. Of the $\mathrm{CD}^{+}$cell antibodies Leu4 produced staining that was easiest to read in the conditions described. Therefore it was used for the subsequent comparisons. Similarly, T4 was used as the reference antibody for $\mathrm{CD}^{+}$cells.

\section{LAMINA PROPRIA LYMPHOCYTES}

In the lamina propria of coeliac children all $\mathrm{T}$ cell subset counts were lower during gluten elimination and challenge than in the biopsies before

TABLE II Number of lymphocytes in the lamina propria of the jejunal biopsies of children with coeliac disease and controls stained with the different antibodies (mean $\left(S E M / \mathrm{mm}^{2}\right)$ )

\begin{tabular}{llllll}
\hline \multicolumn{5}{c}{ Children with coeliac disease } & \\
\cline { 2 - 5 } & $\begin{array}{l}\text { Before } \\
\text { treatment }\end{array}$ & $\begin{array}{l}\text { Gluten } \\
\text { free diet }\end{array}$ & $\begin{array}{l}\text { Gluten } \\
\text { challenge }\end{array}$ & $\begin{array}{l}\text { Controls } \\
n=17\end{array}$ \\
Type of cell & $n=11$ & $n=20$ & $n=13$ \\
\hline CD3 & $1707(136)$ & $1565(82)^{\star}$ & $1468(65)^{\star}$ & $1963(189)$ \\
CD4 & $1323(135)$ & $1123(50)^{\star}$ & $1076(78)^{\star}$ & $1502(159)$ \\
CD8 & $756(117)$ & $680(36)^{\star}$ & $655(35)^{\star}$ & $919(104)$ \\
CD4/CD8 ratio & 1.93 & 1.70 & 1.67 & 1.70 \\
\hline
\end{tabular}

${ }^{\star}$ Difference from the controls; $p<0.05$. 
treatment, or in the controls (Table II). In the 11 patients in whom jejunal biopsies during gluten free diet and gluten challenge were available, the dietary switch caused no observable changes in any lamina propria cell counts (data not shown).

The $\mathrm{CD}^{+} / \mathrm{CD}^{+}$ratio in the patients remained similar to that of the controls and virtually unchanged throughout the follow up.

The lamina propria $\mathrm{CD}^{+}$and $\mathrm{CD}^{+}$lymphocyte counts showed a weak positive correlation $(\mathrm{R}=0.43, \mathrm{p}=0.14$, and $\mathrm{R}=0.41, \mathrm{p}=0.17$, respectively) with the age in the controls. In the patients no correlation with age could be observed.

\section{IN TRAEPITHELIAL LYMPHOCYTES}

Intraepithelial $T$ cell numbers in the surface epithelium showed significant changes in concert with the dietary changes (Table III). During gluten containing diet the numbers of all lymphocyte subpopulations were significantly higher than in patients on gluten elimination diet, or in the controls.

The numbers of $\mathrm{CD}^{+}$intraepithelial lymphocytes equalled the sum of $\mathrm{CD}^{+}$and $\mathrm{CD} 8^{+}$cells in the controls (Fig 1). In the coeliac patients, however, the numbers of $\mathrm{CD}^{+}$cells exceeded the sum of $\mathrm{CD}^{+}{ }^{+}$and $\mathrm{CD} 8{ }^{+}$cells. The percentage of $\mathrm{CD}^{+}$cells unidentified by either $\mathrm{CD} 4$ or $\mathrm{CD} 8$ antibodies was $10 \cdot 5 \%$ before treatment, $14.9 \%$ during gluten-free diet and $20 \cdot 6 \%$ during gluten challenge. The 'unidentified' cell population was significantly greater $(\mathrm{p}<0.05)$ in patients than in the controls $(0 \cdot 1 \%)$.

In the crypt epithelium the $T$ cell numbers were roughly one-third of those within surface epithelium, and the changes during dietary changes closely resembled those observed among surface intraepithelial lymphocytes (Fig 2).

The age of the subject had an observable positive correlation with surface $\mathrm{CD}^{+}(\mathrm{R}=$ $0.65, \mathrm{p}<0.02)$ and $\mathrm{CD}^{+}(\mathrm{R}=0.54, \mathrm{p}=0.056)$, intraepithelial lymphocyte counts in the structurally normal biopsies from the controls. The correlation coefficients of other lymphocyte subpopulations with age were smaller, and statistically insignificant, but invariably positive. In the coeliac patients, whether treated or not, the correlation between age and intraepithelial lymphocyte numbers was obscured.

PERIPHERAL BLOOD LYMPHOCYTES

In peripheral blood the numbers of $\mathrm{CD}^{+}$and $\mathrm{CD}^{+} \mathrm{T}$ cells showed little or no variation with

TABLE III Number of lymphocytes (cells/mm of epithelium) within surface epithelium of the jejunal biopsies of children with coeliac disease and controls stained with the different antibodies (mean $\left(S E M / \mathrm{mm}^{2}\right)$ )

\begin{tabular}{lllll}
\hline \multicolumn{5}{c}{ Children with coeliac disease } \\
\cline { 2 - 4 } & $\begin{array}{l}\text { Before } \\
\text { treatment }\end{array}$ & $\begin{array}{l}\text { Gluten } \\
\text { free diet }\end{array}$ & $\begin{array}{l}\text { Gluten } \\
\text { challenge }\end{array}$ & \multicolumn{1}{l}{$\begin{array}{l}\text { Controls } \\
\text { Type of cell }\end{array}$} \\
$n=11$ & $n=20$ & $n=17$ & $n=13$ \\
\hline CD3 & $60 \cdot 9(10 \cdot 2)+39 \cdot 0(3 \cdot 3)^{\star}$ & $85 \cdot 0(6 \cdot 3) \ddagger$ & $27 \cdot 9(3 \cdot 6)$ \\
CD4 & $3 \cdot 9(0 \cdot 8)^{\star}$ & $2 \cdot 3(0 \cdot 3)$ & $3 \cdot 1(0 \cdot 4)^{\star}$ & $1 \cdot 5(0 \cdot 4)$ \\
CD8 & $50 \cdot 6(8 \cdot 1)^{\star}$ & $30 \cdot 9(3 \cdot 0)$ & $64 \cdot 4(4 \cdot 4) \neq$ & $26 \cdot 3(4 \cdot 0)$ \\
CD4 /CD8 ratio & $0 \cdot 077$ & $0 \cdot 081$ & $0 \cdot 049$ & $0 \cdot 066$ \\
\hline
\end{tabular}

${ }^{\star}$ Difference from the controls; $p<0.05 ; \nmid p<0 \cdot 01 ; \neq p<0.001$

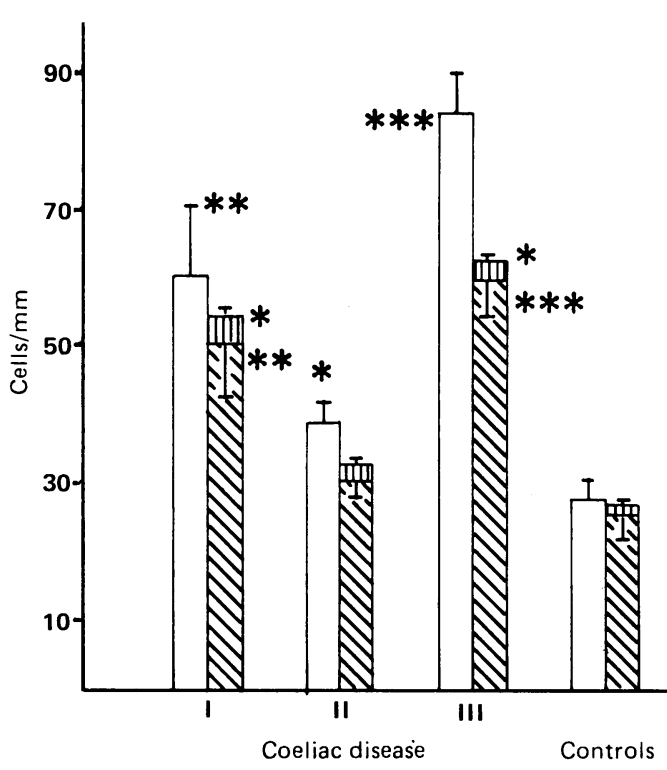

Figure 1: Lymphocyte subpopulations within the jejunal surface epithelium of children with coeliac disease at different stages of dietary treatment and controls. Symbols: Open columns $=C D{ }^{+}$cells; hatched columns $=C D 8^{\prime}$ cells; vertically hatched columns $=C D 4^{+}$cells. $I=$ patients before treatment; $I I=$ patients on gluten-free diet; $I I I=$ patients after gluten challenge. ${ }^{\star}, \star \star, \star \star \star$ denote a significant difference from the controls, with $p$ values less than $0.05,0.01$ and 0.001 , respectively.

regard to the dietary changes in the coeliac patients. The $\mathrm{CD}^{+} / \mathrm{CD}^{+}$ratio showed neither a correlation with, nor a constant difference from that in the intestine. The percentage of $\mathrm{CD}^{+}$ cells unidentified by either CD4 or CD8 antibodies was relatively high in the treated patients $(14.9 \%)$, and lower in patients before treatment $(0.0 \%)$ or during gluten challenge $(4.9 \%)$, or in the controls $(3 \cdot 5 \%)$.

\section{Discussion}

The results of an immunohistochemical study of lymphocyte subsets in children with coeliac disease and control subjects are presented. Six of the patients do not yet fulfill the ESPGAN diagnostic criteria of coeliac disease, ${ }^{10}$ but they have other diseases associated with it, and were well past infancy at the initial jejunal biopsy showing typical histological lesions. Of more than 100 children attending our gastrointestinal services, who have had severe villous atrophy at two years of age or later, every one has eventually fulfilled the ESPGAN criteria of coeliac disease.

In the lamina propria $\mathrm{CD}^{+}$was the predomi-

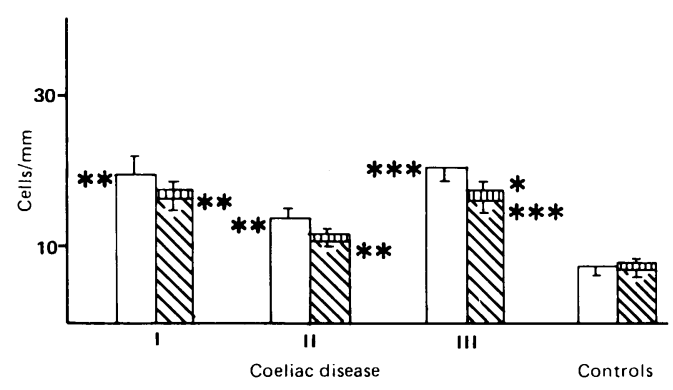

Figure 2: Lymphocyte subpopulations within the jejunal crypt epithelium of controls and children with coeliac disease at different stages of dietary treatment. Symbols: see legend to Figure 1 . 
nating $\mathrm{T}$ cell type. The observed low LP cell counts in patients during later diagnostic stages, and as compared with the controls (Table II), is an unexpected finding, the significance of which is further obscured by the fact that no decrease was observed in the 11 patients in whom both the pre and postchallenge biopsies were available.

In lamina propria the sum of $\mathrm{CD}^{+}$and $\mathrm{CD} 88^{+}$ cells exceeded the number of $\mathrm{CD}^{+}$cells in all the subject groups studied. This difference remained virtually unchanged throughout the diagnostic stages, and resembled the findings in healthy controls. This observation, being in contrast with that made of intraepithelial lymphocytes, indicates a marked difference in surface marker expression and differentiation between lamina propria and intraepithelial lymphocyte $T$ cells, which may be because of weak expression of CD3 antigens, or, hypothetically to the presence of double positive $\left(\mathrm{CD}^{+}{ }^{+}{ }^{+}\right)$cells. The relative constancy of these findings in the patients throughout the study, and similarity to the findings in controls, suggest that in coeliac disease the main $\mathrm{T}$ cell abnormality could be found in the intraepithelial lymphocyte, and not in lamina propria lymphocyte populations.

In contrast with the relatively small changes observed in lamina propria, the intraepithelial T cell numbers showed marked variations in concert with the dietary changes in the coeliac patients, as has been reported. ${ }^{3+6} \mathrm{We}$ observed a similar gap between the numbers of $\mathrm{CD}^{+}$cells and the sum of $\mathrm{CD}^{+}$and $\mathrm{CD} 8^{+}$cells as Jenkins and coworkers 8 in their adult patients with active disease. We also found a significant proportion of $\mathrm{CD}^{+}$cells unidentified by either $\mathrm{CD} 4$ or CD8 antibodies in the histologically normal jejunal biopsies of treated coeliac patients, who also showed somewhat higher intraepithelial lymphocyte counts than the controls. This finding could have at least two explanations. First, there may be minor errors in the most strictly observed diet, causing intraepithelial lymphocyte activation and inconsistent surface marker expression. ${ }^{13}$ An alternative explanation is that the 'unidentified' $\mathrm{CD}^{+}$cells could represent the recently described $\mathrm{CD}^{+} 4^{-} 8^{-}, \gamma \delta$-receptor bearing cells. ${ }^{1+15}$ Such a cell population, being present even in the structurally normal jejunal mucosa of coeliac patients, could have an important role in the pathogenesis of the disease. The appearance of a similar $T$ cell population in the peripheral blood of the patients when gluten is withheld, could reflect a decrease in the local immunological and chemotactic activity, which conceivably would release the $\mathrm{CD}^{+} 4^{-} 8^{-}$cells into the circulation. We are presently pursuing to define the $T$ cell receptors of this cell population.

James et $a l^{16}$ reported that among isolated intestinal lamina propria lymphocytes the proportion of $\mathrm{CD}^{+}$cells was greater than in peripheral blood. We could not confirm this observation. The reason may be in different methods of intestinal cell enumeration, or in the fact that we used only proximal jejunal biopsies, whereas
James $e t$ al isolated cells from various parts of the GI canal. We, like Rodgers et $a l^{17}$ found similar $\mathrm{CD}^{+} / \mathrm{CD}^{+}$ratios in lamina propria and peripheral blood of healthy control subjects.

The observed positive correlations between age and $\mathrm{CD}^{+}$and $\mathrm{CD} 8^{\mathrm{x}}$ intraepithelial lymphocyte counts in our small number of healthy controls warrant further study. If confirmed, this observation of a trend contrasting the general tendency seen in - for example, peripheral blood and lymphatic tissues, might provide material for better understanding of mucosal immune responses. In the patients with coeliac disease the rather weak correlations observed may be obscured by the inevitable patient-topatient variation in the strictness of the glutenfree diet, or possibly by age-related changes in the peculiar $\mathrm{CD}^{+} 4^{-} 8^{-}$intraepithelial lymphocyte population. Dr Arato was a recipient of a Nestle Scholarship while doing
this research. This work was supported in part by grants from this research. This work was supported in part by grants from
the Sigrid Jusélius Foundation, the Foundation for Paediatric the Sigrid Jusélius Foundation, the Foundation for Paediatric
Research, and the State Medical Research Council (Finland). The Research, and the State Medical Research Council (Finland). The
skilful technical assistance of Ms M Appelqvist and Ms Terttu skilful technical assistance of Ms $M$
Louhio is gratefully acknowledged.

Presented in part at the XX Annual Meeting of the European Society for Paediatric Gastroenterology and Nutrition, Lisbon, 24-26 June 1987.

1 Selby WS, Janossy G, Goldstein G, Jewell DP. T lymphocyte subsets in human intestinal mucosa: the distribution and subsets in human intestinal mucosa: the distribution and 1981;44:453-8.

2 Cerf-Bensussan N, Schneeberger EE, Bhan AK. Immunohistologic and immunoelectron microscopic characterization of the mucosal lymphocytes of human small intestine by the use of monoclonal antibodies. F Immunol 1983; 130: 2615-22.

3 Flores AF, Winter HS, Bhan AK. In situ characterisation of T cell subpopulations in gluten sensitive enteropathy (GSE). Pediatr Res 1982; 16: 161A.

4 Selby WS, Janossy G, Bofill M, Jewell DP. Lymphocyte subpopulations in the human small intestine. The findings in normal mucosa and in the mucosa of patients with adult coeliac normal mucosa and in the mucosa of patients

5 Kuitunen P, Kósnai I, Savilahti E. Morphometric study of the jejunal mucosa in various childhood enteropathies with special reference to intraepithelial lymphocytes. $\mathcal{F}$ Pediatr Gastro enterol Nutr 1982; 1: 525-31

6 Kelly J, O'Mahoney C, O'Farrelly C, Feighery C, Weir DG. Inflammatory cell subpopulations in normal and coeliac smal intestinal mucosa. [Abstract] Gut 1985; 26: Al141

7 Malizia G, Trejdosiewic LK, Wood GM, Howdle PD, Janossy G, Losowsky MS. The microenvironment of coeliac disease: $T$ cell phenotypes and expression of the T2 'T blast' antigen by cell phenotypes and expression of the $T 2$ ' $T$ blast' antigen by

small bowel lymphocytes. Clin Exp Immunol 1985; 60: 437-46. Jenkins D, Goodall A, Scott BB. T-lymphocyte populations in
normal and coeliac intestinal mucosa defined by monoclonal normal and coeliac intestinal mu.

9 Vetvicka V, Tlaskaslova-Hogenova H, Fric P, Brochier J. Subpopulations of circulating lymphocytes in adults with coeliac disease. Immunol Lett 1986; 13: 15-8.

10 Meeuwisse G. Diagnostic criteria in coeliac disease. Acta Paediatr Scand 1970; 56: 461-3.

11 Tainio V-M. Lymphocyte subsets in infants: Relationship to feeding, atopy, atopic heredity and infections. Int Arch Allergy Appl Immunol 1985; 78: 305-10.

12 Dixon WJ, ed. BMDP statistical software 1981. Berkeley, California: University of California Press, 1981.

13 Reinherz EL, Meuer SC, Schlossman SF. The delineation of antigen receptors on human T lymphocytes. In: Inglis JR, ed. antigen receptors on human T lymphocytes. In: Inglis

14 Brenner MB, McLean J, Dialynas DP, et al. Identification of a putative second T-cell receptor. Nature 1986; 322: 145-9.

15 Borst J, Van Dongen JJM, Bolhuis RLH, et al. Distinct molecular forms of human T cell receptor $\gamma$ d detected on viable $T$ cells by a monoclonal antibody. $\mathcal{F} \operatorname{Exp}$ Med 1988; 167 $1625-44$.

16 James SP, Fiocchi C, Graeff AS, Strober W. Phenotypic analysis of lamina propria lymphocytes. Predominance of helper-inducer and cytolytic T-cell phenotypes in Crohn's disease and control patients. Gastroenterology 1986; 91: 1483-9.

17 Rodgers VD, Fassett R, Kagnoff MF. Abnormalities in intestinal mucosal $\mathrm{T}$ cells in homosexual populations including those with the lymphadenopathy syndrome and acquired immunodeficiency syndrome. Gastroenterology 1986; 90: 552-8. 